\title{
Gene Variants of the SLC2A5 Gene Encoding GLUT5, the Major Fructose Transporter, Do Not Contribute to Clinical Presentation of Acquired Fructose Malabsorption.
}

Irina Taneva

Medical Laboratory for Clinical Chemistry, Microbiology, Infectious Diseases and Genetics

"Prof.Schenk/Dr.Ansorge \& Colleagues"

Dorothee Grumann

Medical Laboratory for Clinical Chemistry, Microbiology, Infectious Diseases and Genetics

"Prof.Schenk/Dr.Ansorge \& Colleagues"

Dietmar Schmidt

Medical Office Internal Medicine \& Gastroenterology

Elina Taneva

Medical Laboratory for Clinical Chemistry, Microbiology, Infectious Diseases and Genetics

"Prof.Schenk/Dr.Ansorge \& Colleagues"

Ulrike von Arnim

Department of Gastroenterology, Hepatology and Infectious Diseases, Otto-von-Guericke University

Thomas Ansorge

Medical Laboratory for Clinical Chemistry, Microbiology, Infectious Diseases and Genetics

"Prof.Schenk/Dr.Ansorge \& Colleagues"

Thomas Wex ( $\nabla$ t.wex@schenk-ansorge.de )

Medical Laboratory for Clinical Chemistry, Microbiology, Infectious Diseases and Genetics

"Prof.Schenk/Dr.Ansorge \& Colleagues"

\section{Research Article}

Keywords: fructose malabsorption, SLC2A5, GLUT5, promoter

Posted Date: January 24th, 2022

DOI: https://doi.org/10.21203/rs.3.rs-1227373/v1

License: (1) (i) This work is licensed under a Creative Commons Attribution 4.0 International License. Read Full License 
Version of Record: A version of this preprint was published at BMC Gastroenterology on April 6th, 2022. See the published version at https://doi.org/10.1186/s12876-022-02244-7. 


\section{Abstract}

Background: While role of $A L D O B$-related gene variants for hereditary fructose intolerance is well established, contribution of gene variants for acquired fructose malabsorption (e.g. SLC2A5, GLUT5) is not well understood.

Methods: Patients referred to fructose breath test were further selected to identify those having acquired fructose malabsorption. Molecular analysis included (I) exclusion of three main $A L D O B$ gene variants causing hereditary fructose intolerance and (II) sequencing analysis of genomic region comprising of complete coding region, at least $20 \mathrm{bp}$ of adjacent intronic regions and $700 \mathrm{bp}$ of proximal promoter.

Results: Thirty-five individuals with acquired fructose malabsorption were identified among 494 patients based on pathological fructose-breath test and normal lactose-breath test. 34 patients (97\%) had negative tissue anti-transglutaminase and /or deamidated gliadin antibodies in their medical records. Molecular analysis of SLC2A5/GLUT5 gene of all 35 subjects identified five frequent and five singular gene variants mostly in noncoding regions (promoter and intron). Allele frequencies of gene variants were similar to those reported in public databases strongly implying that none of them was significantly associated with acquired fructose malabsorption.

Conclusions: Gene variants of coding exons, adjacent intronic regions and proximal promoter region of $S L C 2 A 5$ gene are unlikely to contribute to genetic predisposition of acquired fructose malabsorption.

\section{Introduction}

Gastrointestinal symptoms are frequent causes for medical check-up in medical office and clinics as well. Pathophysiological mechanisms are numerous including infectious causes (viral, bacterial, parasites), immunologically-related disorders (e.g. reflux disease, gastritis, coeliac disease, and chronic inflammatory bowel disease), intolerance towards nutrients or components (e.g. food-related allergies) and malabsorption syndromes of nutrients such as lactose (1) and fructose (2) as most common ones.

Malabsorption syndromes have rarely monogenic causes. Pathogenic mutations strongly affecting function of lactase $(1,3)$ or aldolase B $(2,4)$ as key enzymes for metabolizing lactose and fructose, respectively, are present in very few subjects. The overall majority of patients suffering from lactose- and fructose-related symptoms are caused multifactorally by hereditary, environmental, sociology-economic factors;in particular diet plays are major role. Lactose-related disorders had been widely studied for decades and have been comprehensively understood concerning its multi-factorial pathogenesis including genetic polymorphisms (5-7). In contrast, fructose-related disorders are not well understood. Notably, fructose-associated disorders have sharply increased over the last 2 decades strongly associated with increasing demand of fructose consumption in a variety of food (8-10). Incomplete intestinal absorption of fructose can lead to various symptoms in vulnerable subjects such as flatulence, diarrhea, bloating, nausea and pain (10-12). Routinely, diagnosis of fructose malabsorption syndrome is mainly performed by hydrogen breath test after ingestion of defined amount of fructose (12). Several 
studies demonstrated pathophysiological role of fructose transporters, in particular GLUT5, for the development of fructose-associated symptoms, although divergent results were reported. Mice experiments (either knockout or feeding models) highlighted a predominant role of s/c2a5 gene (glut5) as major intestinal transporter for fructose and signaling molecule for the induction of down-stream acting genes encoding fructolytic and gluconeogenic enzymes (13-15). Furthermore, slc2a5 - mRNA was found to be regulated by age and fructose in rat model $(16,17)$. In human intestinal cell line models fructose was shown positively regulate SLC2A5/GLUT5 expression by transcriptional and posttranscriptional regulation $(18,19)$, however ex vivo studies of human samples did not show differences in SLC2A5-mRNA or GLUT5 protein content in intestinal biopsies from patients with fructose intolerance (20). In addition to GLUT5 in intestine, the glucose-transporter GLUT2 contributes to the hepatic uptake of fructose since GLUT5 is weakly expressed in liver (21). Very recently, several studies revealed potential regulatory role of GLUT5 for malignancy and proliferation of various tumor cells driven by high consumption of fructose as carbon source $(22,23)$. Based on these recent observations, diagnostic and therapeutic potential of targeting this metabolic pathway has been started to be investigated (24-27). The only study addressing the role of gene variants of SLC2A5/GLUT5 for the development of fructose malabsorption studied 8 patients suffering from isolated fructose malabsorption without finding any functionally relevant gene variant. Mutational analysis was performed by single strand conformation polymorphism analysis and in one index case by Sanger sequencing (28). In order to analyze potential role of SLC2A5/GLUT5 gene variants in a larger cohort, a genomic region comprising of complete coding region, adjacent introns and $700 \mathrm{bp}$ of proximal promoter region of 35 subjects with acquired fructose malabsorption were comprehensively analyzed by Sanger sequencing.

\section{Laboratory Methods}

\section{Study design and patients}

Study design was composed of retrospective and prospective parts (Figure 1). Patients were included between 01.01.2013 and 31.02.2017. Patients referred to perform fructose-breath test in our center $(n=494)$ were screened for abnormal results suggesting malabsorption of fructose. Among 167 patients with abnormal fructose breath test results, 86 presented normal results for lactose-breath test. Fifty-one patients from one gastroenterological center were selected allowing assessment of gastrointestinal symptoms by retrospective study of medical records. All 51 patients were invited to the study by phone and/or personal interview. Overall, 35 patients agreed participating to the study and provided signed informed consent. Study was performed in accordance with the Helsinki Declaration and the study and experimental protocols were approved by the Ethic Committee of the Land Sachsen-Anhalt (Vote No. 19/15).

Taken together, inclusion criteria were: (I) age > 18 years, (II) presence of symptoms implying upper gastrointestinal disorders, (III) lack of three major gene variants of the $A L D O B$-gene causing hereditary fructose intolerance, (IV) pathological fructose-breath test and (V) normal lactose-breath test;details in figure 1. 


\section{Lactose - / Fructose Breath Test}

Breath tests were performed by routine methods. After 12 hours fasting interval (not eating or drinking), patients were challenged with either $50 \mathrm{~g}$ lactose or $25 \mathrm{~g}$ fructose, dissolved in $200 \mathrm{ml}$ water. Proportion of $\mathrm{H}_{2}$ in breath samples were analyzed every 30 min for maximal period of 3 hours. After identifying an increase of $\mathrm{H}_{2}$ samples were taken every 10-15 min. Generally, pathological findings for both breath tests were defined as increase of hydrogen content $>20 \mathrm{ppm}$ compared to baseline (time point 0 ) and/or presence of gastrointestinal symptoms during test period. The presence of symptoms was assessed up to $8 \mathrm{~h}$ after test initiation by phone on the next day. For study purpose, pathological fructose-breath test was considered only if rise of hydrogen $>20 \mathrm{ppm}$ was determined with and without presence of symptoms, while lactose breath test was also considered "positive" if only gastrointestinal symptoms appeared without increase of hydrogen, since about $15 \%$ of all individuals are " $\mathrm{H}_{2}$-non-producer".

\section{Molecular analysis of ALDOB- related SNPs and GLUT5 gene}

Genomic DNA from blood samples were extracted from peripheral blood mononuclear cells using QIACUBE and corresponding DNA extraction kit (Qiagen, Hilden Germany).

Three aldolase $\mathrm{B}(A L D O B)$ - single nucleotide polymorphisms (SNPs) were genotyped by real-time polymerase chain reaction (RT-PCR) using TaqMan ${ }^{\circledR}$ assays with a $7500^{\mathrm{Tm}}$ real-time cycler, in accordance with the manufacturer's instructions (Life Technologies, Carlsbad, California, USA) using Roche light cycler LCII. The three SNPs were: NM_000035.3(ALDOB):c.448G>C (p.Ala150Pro), rs1800546; c.524C>A (p.Ala175Asp), rs76917243 and c.1005C>G (p.Asn335Lys), rs78340951. Based on the absence of these SNPs, aldolase B deficiency could be excluded at $>90 \%$.

Sequence analysis of GLUT5 included untranslated exon 1, all coding exons 2 - 13 with at least 20 bp of corresponding intron-exon boundaries and $700 \mathrm{bp}$ promoter region upstream of untranslated exon 1. PCR products were amplified using Qiagen Hot Start Plus polymerase and M13/M13reverse-tagged primers and conditions as outlined in Table 1 . Standard PCR conditions were: $1 \times 94^{\circ} \mathrm{C}, 5 \mathrm{~min} ; 42 \mathrm{x}\left(94^{\circ} \mathrm{C}, 20 \mathrm{~s} ; 54^{\circ} \mathrm{C}\right.$, $30 \mathrm{~s} ; 72^{\circ} \mathrm{C}, 1 \mathrm{~min}$ ) and $1 \times 72^{\circ} \mathrm{C}, 10 \mathrm{~min}$.

Sequence analysis was performed by standard Sanger sequencing protocols using GeXP platform as described by manufacturer (AbSciex, Darmstadt, Germany). Purification of PCR amplicons and sequencing products were performed using magnetic beads Agencourt AMPure XP and CleanSEQ (Beckman Coulter, Krefeld, Germany) as described by manufacturer. Sequence data were compared with reference sequences published at NCBI (NG_050918.1; NM_001328619.2) using CLC Workbench 8.23 (Qiagen, Hilden, Germany).

\section{Statistical analysis}

Categorical data are expressed as absolute numbers with percentages. Age is shown as a mean with standard deviation. Frequencies of identified gene variants were compared towards public databases 
such as "thousand genome project". Due to the low numbers of most gene variants identified, data are presented descriptively in most cases. If possible, allele frequencies were analyzed by $\chi 2$ test. Differences were considered statistically significant when $p<0.05$.

\section{Results}

\section{Characterization of study group}

As summarized in Table 1, the majority of patients was female (29/35) and the mean age was about 38 years. Retrospective evaluation of clinical records revealed abdominal pain and diarrhea as leading symptoms. Data concerning the duration of symptomatic disease was available for $40 \%$ of the study group. Furthermore it was shown that 34 out of the 35 patients analyzed had negative serology for coeliac disease; either anti-deamidated gliadin IgG and IgA antibodies $(n=30)$ or anti- tissue transglutaminase $\lg \mathrm{G} / \lg \mathrm{A}(\mathrm{n}=4)$ (Table 2$)$.

\section{Molecular analysis of SLC2A5(GLUT5)-gene}

Sequence analysis of SLC2A5 gene of 35 patients was successfully performed for all 35 patients. In total, 10 gene variants were identified from those 5 were frequent and five were identified just once (Table 3 ). One heterozygous synonymous gene variant, leaving amino acid p.Leu278 unchanged, was localized in exon 8 of the SLC2A5 gene (Table 3). The five frequent gene variants are located in promoter and adjacent intronic regions and demonstrated frequencies between 10.0 and $47.1 \%$. Comparison of identified allele frequencies between public databases and own data demonstrate similar ranges for frequent variants (Table 3). The five rare variants (including the missense variant) were identified in individual patients only at heterozygous state. Based on the criteria of the guidelines of the "American College of Medical Genetics" (ACMG) none of the gene variants are considered having pathological relevance (Table 3).

\section{Discussion}

Here, we demonstrated that gene variants of $S L C 2 A 5$ gene encoding the fructose transporter GLUT5 are not generally involved in the pathogenesis of acquired fructose malabsorption. Based on the number of subjects studied $(n=35)$ we cannot exclude a rare role of such gen variants in every individual patient suffering from fructose malabsorption, but the rate of these cases having "pathogenic GLUT5 variants" among all these patients are likely to be $<3-5 \%$.

A major strength of the study is the clinically based definition of the study cohort prior to molecular analysis. Related gastrointestinal disorders such as hereditary lactose-intolerance and acquired lactose malabsorption, both leading to pathological lactose breath test, were excluded. Hereditary ALDOB deficiency was practically ruled out by analyzing the three major mutations of ALDOB leading to this disease. Coeliac disease, also considered as chimera among gastrointestinal diseases, was kept out of the study group by two approaches. First, since secondary lactose malabsorption is a well-known leading 
symptom for coeliac disease, these patients were excluded by abnormal lactose breath test. Second, for 34 out of the 35 individuals, corresponding serological parameters (IgA/lgG tissue anti-transglutaminase or deamidated anti-gliadin antibodies) were found to be negative.

The symptoms reported by our patients are rather unspecific and in line with those reported in similar studies with patients (I) suffering from fructose malabsorption tested by breath test (29-31), or (II) classified as having irritable bowel disease (IBS) $(32,33)$. However it is notable that symptoms in our studies were assessed retrospectively only by analyzing patients' medical records, and no structured interview or assessment of questionnaire in context to e.g. IBS-related Rome criteria (34) was performed.

In summary, the 35 subjects included in the molecular analysis of the SLC2A5/GLUT5 gene presented (I) clinically relevant symptoms that are consistent with acquired fructose-malabsorption, (II) demonstrated abnormal fructose-induced breath test and (III) relevant other related diagnoses (e.g. coeliac disease, hereditary fructose intolerance) were basically excluded. Taken together, we are confident that overall the great majority of these 35 subjects are patients suffering from acquired fructose malabsorption. It has been shown that the individual ability of metabolizing fructose for subjects without any side effects differs widely from 5 - $50 \mathrm{~g}$ (reviewed in 21) supporting the multi-factorial etiology of acquired fructose malabsorption.

The aim of the study, molecular analysis of SLC2A5/GLUT5 gene concerning gene variants associated to fructose malabsorption, was based on other studies showing the role of SNPs/mutations affecting the uptake/metabolism of related sugars. Variants including partial deficiency of sucrose- isomaltase were shown to be associated with IBS (35). Analysis of UK biobank data revealed that gene variants in human ketohexokinase gene are associated with loss of function and resulting in the rare benign condition of fructosuria (36). In vitro mutation analysis in rats between GLUT5 and its closest related transporter (GLUT7) revealed that single amino acids (e.g. p.Gln166Glu) are responsible for the specific transport of fructose, and mutation of this residue to $\mathrm{p} .166 \mathrm{Glu}$ results in the uptake of glucose, whereas other variants and chimera between GLUT5 and GLUT7 demonstrated strong reduction or even complete lack of fructose uptake (37).

The fact that the allele frequencies of the 10 gene variants between ours and those reported in database were very similar strongly implies that none of these variants have a relevant role for the clinical manifestation of acquired fructose malabsorption. Notably, 5 of the 10 gene variants were singular findings that do not allow final any general conclusion due to study size. But taken into account the very low frequencies reported in databases, the potential relevance for the very frequent fructose-absorption syndrome seems to be very limited.

While this study demonstrate that SLC2A5/GLUT5-related gene variants do not playing a relevant role in the pathogenesis of acquired fructose malabsorption, other pathogenic factors have been recently identified to be associated with this disorder. Trelis and co-workers identified a frequent association of the disease with the infection of parasites, in particular Giardia intestinalis (38). Several animal studies identified specific changes in the gut microbiome in context to genetic host factors (39) and the intake of 
fructose $(39,40)$ showing that Akkermansia spec. seems to play an important role in the prevention fructose-induced metabolic dysregulation. Over-expression of $s / c 2 a 5$ in s/c2a5/glut5-knock out mice let to profound increase of fructose utilization and subsequent higher levels of Clostridium and Enterococcus spec. (41). Overall most related studies demonstrate that higher intestinal luminal levels of fructose caused by changes in fructose consumption or absorption will likely affect bacterial load and composition of the microbiome (reviewed in 42).

In humans, several studies highlighted the role of the transcription factor ChREBP encoded by the MLXIPL gene for the predisposition concerning fructose intolerance malabsorption $(21,43)$ and diarrheapredominant IBS patients with impaired intestinal fructose transport (44). The association between ChREBP and fructose malabsorption was further supported by animal models $(45,46)$. Nuclear receptor LXR (Ixralpha, NR1H3) is another transcriptional regulator of GLUT5 expression identified in mice and human that is thought to be a potential pharmaceutical target for selective modulation of GLUT5 expression in context to cancer and metabolic disease (47). Notably, authors identified a functional LXR responsive element in the human SLC2A5/GLUT5 promoter region located at position -385 based on transcriptional start site, but none of our 35 patients showed a variation at this position.

Overall, these different findings strengthen the hypothesis that fructose-related malabsorption syndrome associated with different pathological conditions has multi-factorial etiology. Different transcriptional regulatory patterns affecting the SLC2A5/GLUT5 gene expression contribute to the pathology, whereas gene variants of SLC2A5/GLUT5 including the promoter region, which was the focus of this study, do not play a relevant role.

\section{Declarations}

\section{Ethics approval and consent to participate}

Study scheme and experimental protocols were approved by the Ethic Committee of the Land SachsenAnhalt (Vote No. 19/15). The study was performed in accordance with the Helsinki Declaration. All patients who participated in the study provided signed informed consent.

\section{Consent for publication}

Not applicable.

\section{Availability of data and materials}

All data generated or analysed during this study are included in this published article.

\section{Competing interests}

The authors declare that they have no competing interests.

\section{Funding}


Not applicable

\section{Authors' contributions}

I.T. included patients, acquired data, analyzed primary data, and was involved in writing of the manuscript. D.G. included patients, acquired data, analyzed primary data, and was involved in writing of the manuscript. D.S. included patients and provided retrospective data of study cohort. E.T. was involved in providing funding, planning of study, providing data of breath tests. U.v.A. was involved in study design, assessment of serological data. T.A. was involved in providing funding, planning of study, providing data of breath tests. T.W. was involved in study design, inclusion of patients, primary data analysis, and writing of the manuscript. All authors critically reviewed and approved the manuscript.

\section{Acknowledgments}

Authors like to thank patients for their contributions and other colleagues of the Laboratory "Prof. Schenk/Dr. Ansorge \& Colleagues" not listed as authors.

\section{References}

1. Fassio F, Facioni MS, Guagnini F. Lactose Maldigestion, Malabsorption, and Intolerance: A Comprehensive Review with a Focus on Current Management and Future Perspectives. Nutrients. 2018;10(11). pii: E1599. doi: 10.3390/nu10111599

2. Gibson PR, Newnham E, Barrett JS, et al.: Review article: fructose malabsorption and the bigger picture. Aliment Pharmacol Ther. 2007;25(4):349-63.

3. Wanes D, Husein DM, Naim HY. Congenital Lactase Deficiency: Mutations, Functional and Biochemical Implications, and Future Perspectives. Nutrients. 2019;11(2). pii: E461. doi: 10.3390/nu11020461.

4. Baker P II, Ayres L, Gaughan S, et al.: In: Adam MP, Ardinger HH, Pagon RA, eta et al. Hereditary Fructose Intolerance. GeneReviews ${ }^{\circledR}$ [Internet]. Seattle (WA): University of Washington, Seattle; 19932020.

5. Lukito W, Malik SG, Surono IS, et al. From 'lactose intolerance' to 'lactose nutrition'. Asia Pac J Clin Nutr. 2015;24 Suppl 1:S1-8. doi: 10.6133/apjen.2015.24.s1.01.

6. Ingram CJ, Mulcare CA, Itan Y, et al. Lactose digestion and the evolutionary genetics of lactase persistence. Hum Genet. 2009;124(6):579-91. doi: 10.1007/s00439-008-0593-6.

7. Järvelä IE. Molecular genetics of adult-type hypolactasia. Ann Med. 2005;37(3):179-85.

8. Jones HF, Butler RN, Brooks DA. Intestinal fructose transport and malabsorption in humans. Am J Physiol Gastrointest Liver Physiol. 2011;300(2):G202-6. doi: 10.1152/ajpgi.00457.2010.

9. Ebert K, Witt H. Fructose malabsorption. Mol Cell Pediatr. 2016;3(1):10. doi: 10.1186/s40348-0160035-9. 
10. Hammer HF, Hammer J. Diarrhea caused by carbohydrate malabsorption. Gastroenterol Clin North Am. 2012;41(3):611-27. doi: 10.1016/j.gtc.2012.06.003.

11. Patel C, Douard V, Yu S, Gao N, et al. Transport, metabolism, and endosomal trafficking-dependent regulation of intestinal fructose absorption. FASEB J. 2015; 29(9):4046-58. doi: 10.1096/fj.15272195.

12. Amieva-Balmori M, Coss-Adame E, Rao NS, et al. Diagnostic Utility of Carbohydrate Breath Tests for SIBO, Fructose, and Lactose Intolerance. Dig Dis Sci. 2020;65(5):1405-1413. doi: 10.1007/s10620019-05889-9.

13. Patel C, Douard V, Yu S, et al. Fructose-induced increases in expression of intestinal fructolytic and gluconeogenic genes are regulated by GLUT5 and KHK. Am J Physiol Regul Integr Comp Physiol. 2015;309(5):R499-509. doi: 10.1152/ajpregu.00128.2015.

14. Barone S, Fussell SL, Singh AK et al. Slc2a5 (Glut5) is essential for the absorption of fructose in the intestine and generation of fructose-induced hypertension. J Biol Chem. 2009;284(8):5056-66. doi: 10.1074/jbc.M808128200.

15. Ebert K, Ewers M, Bisha I, et al. Identification of essential amino acids for glucose transporter 5 (GLUT5)-mediated fructose transport. J Biol Chem. 2018;293(6):2115-2124. doi: 10.1074/jbc.RA117.001442.

16. Shu R, David ES, Ferraris RP. Dietary fructose enhances intestinal fructose transport and GLUT5 expression in weaning rats. Am J Physiol. 1997; 272(3 Pt 1):G446-53.

17. Suzuki T, Douard V, Mochizuki K, et al. Diet-induced epigenetic regulation in vivo of the intestinal fructose transporter Glut5 during development of rat small intestine. Biochem J. 2011;435(1):43-53. doi: 10.1042/BJ20101987.

18. Gouyon F, Onesto C, Dalet V, et al. Fructose modulates GLUT5 mRNA stability in differentiated Caco-2 cells: role of cAMP-signalling pathway and PABP (polyadenylated-binding protein)-interacting protein (Paip) 2. Biochem J. 2003;375(Pt 1):167-74.

19. Mesonero J, Matosin M, Cambier D, et al. Sugar-dependent expression of the fructose transporter GLUT5 in Caco-2 cells. Biochem J. 1995; 312 (Pt 3):757-62.

20. Wilder-Smith CH, Li X, Ho SS, et al. Fructose transporters GLUT5 and GLUT2 expression in adult patients with fructose intolerance. United European Gastroenterol J. 2014;2(1):14-21. Doi: $10.1177 / 2050640613505279$.

21. Hannou SA, Haslam DE, McKeown NM, et al. Fructose metabolism and metabolic disease. J Clin Invest. 2018;128(2):545-555. doi: 10.1172/JCI96702.

22. Su C, Li H, Gao W. GLUT5 increases fructose utilization and promotes tumor progression in glioma. Biochem Biophys Res Commun. 2018;500(2):462-469. doi: 10.1016/j.bbrc.2018.04.103.

23. Jin X, Liang Y, Liu D, et al. An essential role for GLUT5-mediated fructose utilization in exacerbating the malignancy of clear cell renal cell carcinoma. Cell Biol Toxicol. 2019;35(5):471-483. doi: 10.1007/s10565-019-09478-4. 
24. Jin C, Gong X, Shang Y. GLUT5 increases fructose utilization in ovarian cancer. Onco Targets Ther. 2019;12:5425-5436. doi: 10.2147/OTT.S205522.

25. Fan X, Liu H, Liu M, et al. Increased utilization of fructose has a positive effect on the development of breast cancer. PeerJ. 2017;5:e3804. doi: 10.7717/peerj.3804.

26. Kannan S, Begoyan VV, Fedie JR, et al. Metabolism-Driven High-Throughput Cancer Identification with GLUT5-Specific Molecular Probes. Biosensors (Basel). 2018;8(2). pii: E39. doi: 10.3390/bios8020039.

27. Tripp J, Essl C, lancu CV, et al. Establishing a yeast-based screening system for discovery of human GLUT5 inhibitors and activators. Sci Rep. 2017;7(1):6197. doi: 10.1038/s41598-017-06262-4.

28. Wasserman D, Hoekstra JH, Tolia V, et al. Molecular analysis of the fructose transporter gene (GLUT5) in isolated fructose malabsorption. J Clin Invest. 1996;98(10):2398-402.

29. Posovszky C, Roesler V, Becker S, et al. Warschburger P. Roles of Lactose and Fructose Malabsorption and Dietary Outcomes in Children Presenting with Chronic Abdominal Pain. Nutrients. 2019; 11(12):3063. doi: 10.3390/nu11123063.

30. Mehta M, Beg M. Fructose Intolerance: Cause or Cure of Chronic Functional Constipation. Glob Pediatr Health. 2018;5:2333794X18761460. doi: 10.1177/2333794X18761460.

31. Hammer V, Hammer K, Memaran N, et al. Relationship Between Abdominal Symptoms and Fructose Ingestion in Children with Chronic Abdominal Pain. Dig Dis Sci. 2018;63(5):1270-1279. doi: 10.1007/s10620-018-4997-4.

32. Nybacka S, Störsrud S, Lindqvist HM, et al. Habitual FODMAP Intake in Relation to Symptom Severity and Pattern in Patients with Irritable Bowel Syndrome. Nutrients. 2020;13(1):27. doi: 10.3390/nu13010027.

33. Jung KW, Seo M, Cho YH, et al. Prevalence of Fructose Malabsorption in Patients With Irritable Bowel Syndrome After Excluding Small Intestinal Bacterial Overgrowth. J Neurogastroenterol Motil. 2018;24(2):307-316. doi: 10.5056/jnm17044.

34. Lacy BE, Patel NK. Rome Criteria and a Diagnostic Approach to Irritable Bowel Syndrome. J Med. 2017;6(11):99. doi: 10.3390/jcm6110099.

35. Ohlsson B. Theories behind the effect of starch and sucrosereduced diets on gastrointestinal symptoms in irritable bowel syndrome (Review).Mol Med Rep. 2021;24(4):732. doi: 10.3892/mmr.2021.12372.

36. Johnston JA, Nelson DR, Bhatnagar P, et al. Prevalence and cardiometabolic correlates of ketohexokinase gene variants among UK Biobank participants. PLoS One. 2021;16(2):e0247683. doi: 10.1371/journal.pone.0247683

37. Ebert K, Ewers M, Bisha I, et al. Identification of essential amino acids for glucose transporter 5 (GLUT5)-mediated fructose transport. J Biol Chem. 2018;293(6):2115-2124. doi: 10.1074/jbc.RA117.001442.

38. Trelis $M$, Taroncher-Ferrer S, Gozalbo M, et al. Giardia intestinalis and Fructose Malabsorption: A Frequent Association. Nutrients. 2019;11(12):2973. doi: 10.3390/nu11122973. 
39. Ahn IS, Lang JM, Olson CA, et al. Host Genetic Background and Gut Microbiota Contribute to Differential Metabolic Responses to Fructose Consumption in Mice. J Nutr. 2020;150(10):27162728. doi: 10.1093/jn/nxaa239.

40. Song M, Li X, Zhang X, et al. Dietary copper-fructose interactions alter gut microbial activity in male rats. Am J Physiol Gastrointest Liver Physiol. 2018;314(1):G119-G130. doi:

10.1152/ajpgi.00378.2016.

41. Schmitt CC, Aranias T, Viel T, et al. Intestinal invalidation of the glucose transporter GLUT2 delays tissue distribution of glucose and reveals an unexpected role in gut homeostasis. Mol Metab. 2016;6(1):61-72. doi: 10.1016/j.molmet.2016.10.008.

42. Ferraris RP, Choe JY, Patel CR. Intestinal Absorption of Fructose. Annu Rev Nutr. 2018;38:41-67. doi: 10.1146/annurev-nutr-082117-051707.

43. Agius L, Chachra SS, Ford BE. The Protective Role of the Carbohydrate Response Element Binding Protein in the Liver: The Metabolite Perspective. Front Endocrinol (Lausanne). 2020;11:594041. doi: 10.3389/fendo.2020.594041.

44. Oh AR, Sohn S, Lee J, et al. ChREBP deficiency leads to diarrhea-predominant irritable bowel syndrome. Metabolism. 2018;85:286-297. doi: 10.1016/j.metabol.2018.04.006.

45. Kato T, lizuka K, Takao K, et al. ChREBP-Knockout Mice Show Sucrose Intolerance and Fructose Malabsorption. Nutrients. 2018;10(3):340. doi: 10.3390/nu10030340.

46. Kim M, Astapova II, Flier SN, et al. Intestinal, but not hepatic, ChREBP is required for fructose tolerance. JCl Insight. 2017;2(24):e96703. doi: 10.1172/jci.insight.96703.

47. Zwarts I, van Zutphen T, Kruit JK, et al. Identification of the fructose transporter GLUT5 (SLC2A5) as a novel target of nuclear receptor LXR. Sci Rep. 2019;9(1):9299. doi: 10.1038/s41598-019-45803-X.

\section{Tables}

Table 1: Primers used for amplification and sequencing. 


\begin{tabular}{|c|c|c|c|}
\hline Region ${ }^{1}$ & Sequence & $\begin{array}{l}\text { fragment size } \\
\text { (bp) }\end{array}$ & $\begin{array}{l}\text { Different conditions from standard } \\
\text { protocol }^{4}\end{array}$ \\
\hline \multirow[t]{2}{*}{ Promotor } & M13-TCTCGCTCTGTCACCCA & \multirow[t]{2}{*}{456} & \multirow[t]{2}{*}{$60^{\circ} \mathrm{C}+\mathrm{QS}$} \\
\hline & $\begin{array}{l}\text { M13rev- } \\
\text { GTCTTTGCCGTAGCCCA }\end{array}$ & & \\
\hline \multirow[t]{2}{*}{ Promotor } & $\begin{array}{l}\text { M13- } \\
\text { TAACAGTAACAGAAACGCTCC }\end{array}$ & \multirow[t]{2}{*}{431} & \multirow[t]{2}{*}{$60^{\circ} \mathrm{C}$} \\
\hline & $\begin{array}{l}\text { M13rev- } \\
\text { CCTAGTGGCTCAAAGATGG }\end{array}$ & & \\
\hline Promotor & M13-GGTCTTGCTCTGTCACCT & \multirow[t]{2}{*}{324} & \multirow[t]{2}{*}{$58^{\circ} \mathrm{C}+\mathrm{QS}$} \\
\hline $\begin{array}{l}\text { Exon } 1 \\
(\text { UTR })^{3}\end{array}$ & $\begin{array}{l}\text { M13rev- } \\
\text { CCCTTCAGCTTCTGCCA }\end{array}$ & & \\
\hline \multirow[t]{2}{*}{ Exon 2} & $\begin{array}{l}\text { M13- } \\
\text { CCCACTTACTTAGCCAAACC }\end{array}$ & \multirow[t]{2}{*}{360} & \\
\hline & $\begin{array}{l}\text { M13rev- } \\
\text { TTCCCTCTGCAACACCA }\end{array}$ & & \\
\hline \multirow[t]{2}{*}{ Exon 3} & $\begin{array}{l}\text { M13- } \\
\text { TTGAGAAAGCCTGTAACCC }\end{array}$ & \multirow[t]{2}{*}{447} & \multirow[t]{2}{*}{ QS } \\
\hline & $\begin{array}{l}\text { M13rev- } \\
\text { CCCATCCCAAGAGACCT }\end{array}$ & & \\
\hline \multirow[t]{2}{*}{ Exon 4} & $\begin{array}{l}\text { M13- } \\
\text { CAGGTTATTTCATTGGGTGTC }\end{array}$ & \multirow[t]{2}{*}{339} & \\
\hline & $\begin{array}{l}\text { M13rev- } \\
\text { TGGTAAGGATTTCAGTTGTAGG }\end{array}$ & & \\
\hline \multirow[t]{2}{*}{ Exon 5} & M13-CCACACTGAGCGTATTCC & \multirow[t]{2}{*}{448} & \multirow[t]{2}{*}{$58^{\circ} \mathrm{C}+\mathrm{QS}$} \\
\hline & $\begin{array}{l}\text { M13rev- } \\
\text { GTTTCACAGCAGAGGTATAGG }\end{array}$ & & \\
\hline \multirow[t]{2}{*}{ Exon 6} & $\begin{array}{l}\text { M13- } \\
\text { CCTTTGATCTGTTTCTCTTTCC }\end{array}$ & \multirow[t]{2}{*}{439} & \multirow[t]{2}{*}{$58^{\circ} \mathrm{C}$} \\
\hline & $\begin{array}{l}\text { M13rev- } \\
\text { AAAGTCCTGTCCTGTGGT }\end{array}$ & & \\
\hline \multirow[t]{2}{*}{ Exon 7} & M13-AAAGCTGTGCCCTCCTG & \multirow[t]{2}{*}{402} & \multirow[t]{2}{*}{$58^{\circ} \mathrm{C}+\mathrm{QS}$} \\
\hline & $\begin{array}{l}\text { M13rev- } \\
\text { ССTTСТСТGССтСАТССтс }\end{array}$ & & \\
\hline \multirow[t]{2}{*}{ Exon 8} & М13-TCTGCTGССCTTCTTCC & \multirow[t]{2}{*}{574} & \multirow[t]{2}{*}{ QS } \\
\hline & $\begin{array}{l}\text { M13rev- } \\
\text { CATGACCACGTTCACGG }\end{array}$ & & \\
\hline
\end{tabular}




\begin{tabular}{|c|c|c|c|}
\hline \multirow[t]{2}{*}{ Exon 9} & M13-CGTGCTGAAGCTGTTCC & \multirow[t]{2}{*}{474} & \multirow[t]{2}{*}{ QS } \\
\hline & $\begin{array}{l}\text { M13rev- } \\
\text { CAGAGTTTCTGTAGTAGCGG }\end{array}$ & & \\
\hline \multirow[t]{2}{*}{ Exon 10} & $\begin{array}{l}\text { M13- } \\
\text { CTCAGGGTTGTGGGATTAGGA }\end{array}$ & \multirow[t]{2}{*}{640} & \multirow[t]{2}{*}{ QS } \\
\hline & $\begin{array}{l}\text { M13rev- } \\
\text { CAGACAAGCTAGGACGGGA }\end{array}$ & & \\
\hline \multirow[t]{2}{*}{ Exon 11} & M13-САTCTGCCTCATAGCCTG & \multirow[t]{2}{*}{602} & \multirow[t]{2}{*}{$58^{\circ} \mathrm{C}+\mathrm{QS}$} \\
\hline & $\begin{array}{l}\text { M13rev- } \\
\text { CTCATTATGTGCCACCCA }\end{array}$ & & \\
\hline \multirow[t]{2}{*}{$\begin{array}{l}\text { Exon 12, } \\
13\end{array}$} & $\begin{array}{l}\text { M13- } \\
\text { CCACATGCCCAAGAGTCCTG }\end{array}$ & \multirow[t]{2}{*}{730} & \multirow[t]{2}{*}{$58^{\circ} \mathrm{C}+\mathrm{QS}$} \\
\hline & $\begin{array}{l}\text { M13rev- } \\
\text { AGCCCTTTGCACAGTTCCC }\end{array}$ & & \\
\hline
\end{tabular}

${ }^{1}$ Numbering of exons is based on reference sequence NG_050918.1 $;^{2}$ sequencing tag M13 (gtaaaacgacggccagt) M13rev (ggaaacagctatgaccatg); ${ }^{3}$ Exon 1 : untranslated region (UTR) ; ${ }^{4}$ Conditions refer to annealing temperature and addition of QS-solution (Qiagen, Hilden, Germany).

Table 2: Demographic and clinical data of study_group. 
Demographic parameter

Gender (m/f)

Age (mean/range)

\section{Symptoms}

abdominal pain

diarrhoea

meteorism

gastroesophageal reflux

irregular stool frequency

obstipation

haematochezia

not defined

\section{Onset of symptoms}

weeks to months

years

not recorded

Serological assessment of coeliac disease

anti- deamidated gliadin lgG/ IgA antibodies: negative

anti-tissue transglutaminase $\lg \mathrm{G} / \lg \mathrm{A}$ : negative

no information
Number / Frequency

$6(17.14 \%) / 29$ (82.86\%)

$38.3(18-68)$

$17(48.6 \%)$

$12(34.3 \%)$

$5(14.3 \%)$

$5(14.3 \%)$

$4((11.4)$

$3(8.6 \%)$

$2(5.7 \%)$

$11(31.4 \%)$

$8(22.9 \%)$

$6(17.1 \%)$

$21(60.0 \%)$

$30 / 35(85.7 \%)$

$4 / 35(11.4 \%)$

$1 / 35(2.9 \%)$

Multiple symptoms were possible. Note that data were retrospectively recorded from medical records of patients; no structured interview was performed.

Table 3: Allele frequencies of GLUT5 gene variants in 35 patients with acquired fructose intolerance 


\begin{tabular}{llll}
$\begin{array}{l}\text { Gene variant } \\
\text { (rs. No.) }\end{array}$ & $\begin{array}{l}\text { NM_001328619.2 } \\
\text { NP_001315548.1 }\end{array}$ & $\begin{array}{l}\text { Allel frequency (\%) Own study/TGP- } \\
\text { Europe/gnomAD-Europe) }\end{array}$ & $\begin{array}{l}\text { Classification based on } \\
\text { ACMG-guidelines } \\
\text { (www.varsome.com) }\end{array}$ \\
\hline rs958806131 & c.-269-247 C>T & $1.4 /$ n.d. / 0.01 & VUS3 \\
\hline rs1705285 & c.-269-213 T>C & $34.3 / 39.0 / 36.1$ & benign \\
\hline rs12117043 & c.-269-202 C>T & $34.3 / 32.2 / 30.8$ & Benign \\
\hline rs35276984 & c.-269-135 ins T & $47.1 / 59.0 / 59.4$ & Benign \\
\hline rs5438 & c.-25 G>A & $1.4 / 5.8 / 5.6$ & VUS3 \\
\hline rs3737661 & c.294-56 C>A & $10.0 / 5.1 /$ n.d. & likely benign \\
\hline rs139477702 & $\begin{array}{l}\text { c. } 832 ~ C>T, \\
\text { p.Leu278= }\end{array}$ & $1.4 / 0.2 / 0.3$ & likely benign \\
\hline rs11121306 & c. $1098+145$ C>T & $28.6 / 27.4 / 26.3$ & Benign \\
\hline rs370588099 & c. $1175-38$ G>A & $1.4 /$ n.d. / 0.01 & VUS3 \\
\hline unknown & c. $1302+21$ A >C & $1.4 /$ n.d. / n.d. & unknown
\end{tabular}

(TGP: Thousand Genome Project; https://www.internationalgenome.org/data/ ; gnomAD: Genome Aggregation Database; https://gnomad.broadinstitute.org/)

\section{Figures}




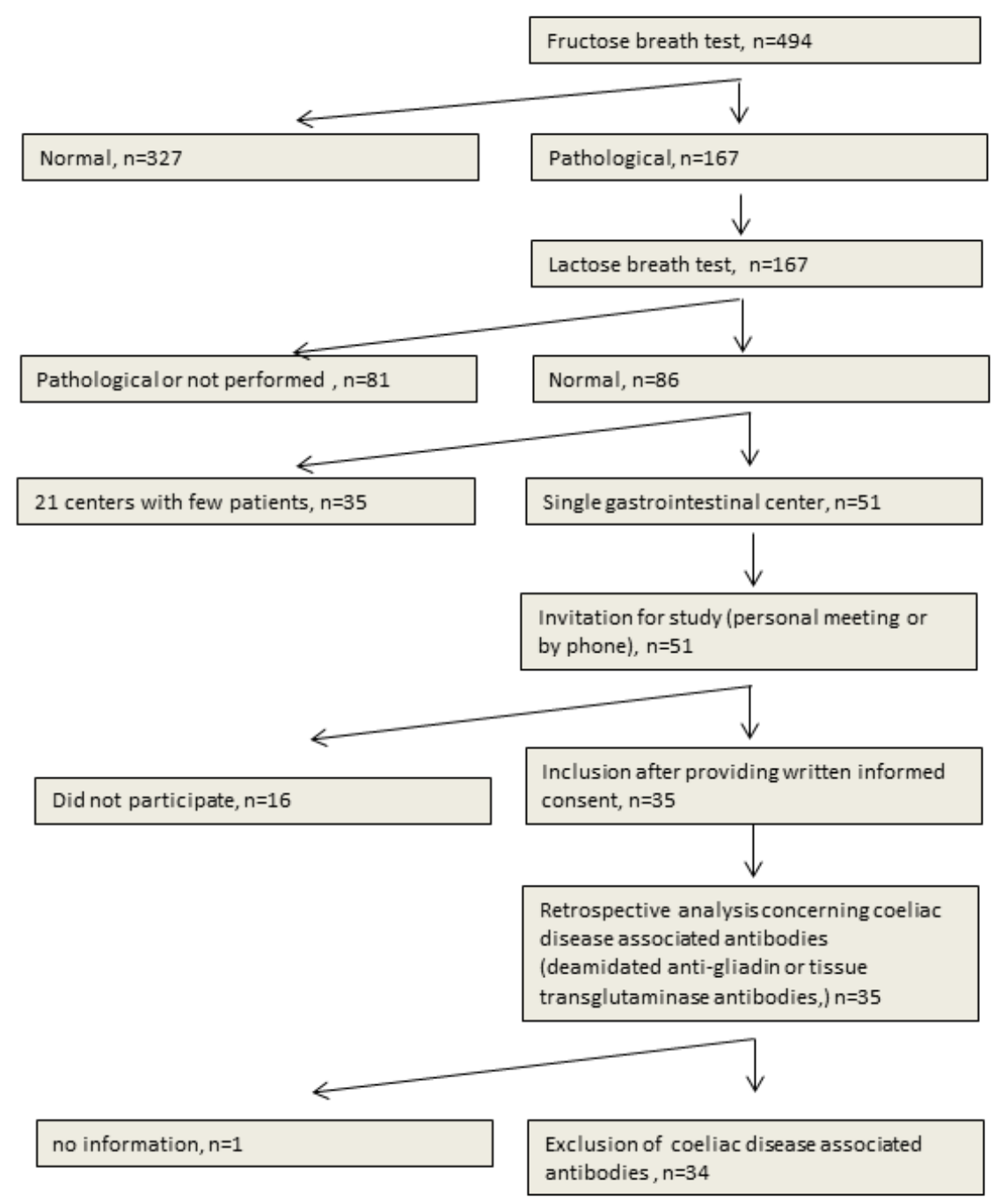

Figure 1

Study scheme 